\title{
KOMPARASI EFEK PEMBERIAN MINYAK JINTAN HITAM (Nigella sativa) DENGAN MINYAK ZAITUN (Olea europea) TERHADAP PENURUNAN GLUKOSA DARAH PADA MENCIT (Mus musculus) STRAIN Balb/c
}

\author{
Setyo Dwi Santoso'), Imam Suryanto ${ }^{2)}$ \\ ${ }^{1), 2)}$ Dosen Fakultas Ilmu Kesehatan, Univesitas Maarif Hasyim Latif, Sepanjang, Sidoarjo \\ Email : setyo.d.santoso@gmail.com
}

\begin{abstract}
Diabetes mellitus is a disease in humans characterized by an increase in blood glucose levels exceeds the normal limits. Cumin oil and olive oil is an alternative drug to a decrease in blood glucose levels for people with diabetes mellitus. Cumin oil and olive oil has several compounds that can lower blood glucose levels in excess. This study was conducted in January 2015 for 3 weeks in PUSVETMA Surabaya. Animals used in the study were female mice 2-3 months old with an average weight of 20-25 grams of a much as 30 individuals. At a dosage of dextrose $40 \%$ is $0.4 \mathrm{cc} /$ head / day and the dosage of cumin oil and olive oil is 0.7 cc / head / day. This a study conducted of mice that had been induced dextrose $40 \%$ by using a sample of a much as 30 female mice. The results of statistical independent t-test, there was no difference or both of the test sample may lower blood glucose levels among female mice were treated with cumin oil and treated with olive oil. While the results of the data was tested using SPSS statistical Paired t-test showed that effectively lower blood glucose levels are olive oil, because there is a significant difference between before and after administration of olive oil after 7 days of dosing.
\end{abstract}

Keyword : Cumin Oil, Olive oil, Mice (Balb/c), Dextrose 40\%, Blood Glucose

\section{PENDAHULUAN}

Diabetes mellitus merupakan penyakit metabolik sebagai akibat kurangnya insulin efektif karena adanya disfungsi sel beta pancreas glukosa di jarigan perifer atau keduanya (Diabetes Melitus Tipe 2). Kurangnya insulin absolut
(Diabetes Melitus Tipe 1) dengan beberapa gejala diantara hiperglikemia dan glukosuria yang disertai gejala akut. Gangguan primer terletak pada metabolisme karbohidrat dan gangguan sekunder yang terletak pada metabolism lemak dan protein (Tjokroprawiro, 2006). 
Mengingat bahayanya penyakit diabetes melitus, maka penggunaan obat merupakan pilihan utama dalam menanganinya. Obat yang sering dipergunakan untuk terapi diabetes melitus adalah golongan sulfonilurea dan biguanid - Penggunaan obat anti diabetes biasanya berlangsung lama dengan efek samping yang ditimbulkan cukup besar (Nolte dan Karam, 2002).

Berdasarkan hal itu, maka diperlukan suatu alternatif pengobatan yang harganya relatif murah dan khasiatnya tidak berbeda jauh dengan obat sintetik. Salah satu alternatif pengobatan tersebut adalah penggunaan obat tradisional dari tanaman alam (Miladiyah, et al, 2003).

Penggunaan obat tradisional dari tanaman alam salah satu diantaranya adalah Jintan Hitam (Nigella sativa L). Biji dari tanaman Jintan Hitam (Nigella sativa L.) ini memiliki kandungan kimia berupa asam linoleat, asam oleat, asam palmitat, asam stearat, asam laurat, asam miristat serta asam linolenat (Nickavar et al, 2003). Jintan hitam juga mengandung volatil oil yang komponen utamanya adalah thymoquinone (Al-Majed et al, 2006).

Jintan Hitam diketahui mempunyai banyak efek farmakologis seperti antiinflamasi, analgesik, antipiretik, antimikroba, antihelmentik, antikanker, diuretik, bronkodilator, immunostimulator, hepatoprotektor, renoprotektor, antidiare, antidiabetes (efek hipoglikemik), antihipertensi, spasmolotik, dan antioksidan (Yulianti dan Junaedi, 2007; Meral et al, 2004).

Tanaman obat herbal yang lain yang memiliki manfaat yang sama dengan Jintan Hitam adalah Minyak Zaitun. Minyak Zaitun merupakan minyak yang mengandung asam lemak tak jenuh tunggal sebagai komponen utamanya. Sebagai komponen terbesar, asam lemak tak jenuh tunggal dalam minyak zaitun memiliki manfaat sebagai terapi nutrisi bagi penderita diabetes melitus. Hal ini dikatakan dengan peningkatan aktivitas insulin, yaitu meningkatkan sensitivitas insulin pada jaringan yang dituju, peningkatan sekresi insulin dan memperbaiki sel-sel beta pankreas (De Bruyne et al, 2008).

Penerapan herbal pada manusia harus melalui eksperimen, eksperimen ini yang dimaksud adalah dengan menggunakan hewan coba. Hewan coba untuk keperluan penelitian yang bertujuan untuk terapi kesehatan manusia diperlukan pemilihan yang tepat untuk tujuan ekstrapolasi dari hasil in vivo di hewan coba keperawalan kesehatan manusia dibutuhkan pengetahuan dan pengalaman berkelanjutan (Suryanto, 1993). Hewan coba yang hasil penelitiannya dapat diekstrapolasikan pada manusia adalah Mus musculus (Mangkoewidjojo S., 2003).

Dari uraian di atas, perlu dilakukan penelitian mengenai komparasi efek jintan hitam dengan minyak zaitun terhadap penurunan glukosa darah pada mencit strain Balb/c.

\section{METODOLOGI PENELITIAN}

Data yang diperoleh diuji secara statistik menggunakan uji independent $t$ test untuk mengetahui ada atau tidak adanya perbedaan antara yang diberi perlakuan minyak jintan hitam dan minyak zaitun dalam menurunkan kadar glukosa darah pada mencit dan uji Paired t-test untuk mengetahui perbedaan sebelum dan 
sesudah diberi perlakuan dengan menggunakan minyak jintan hitam dan minyak zaitun.

\section{Waktu dan Tempat Penelitian}

Sampel dalam penelitian ini berupa minyak jintan hitam dan kinyak zaitun komersil. Penelitian dilakukan di IKHP (Instalasi Kandang Hewan Percobaan) PUSVETMA (Pusat Veteriner Farma) Surabaya. Penelitian dilakukan selama 3 minggu.

\section{Alat dan Bahan Penelitian}

Kandang plastik polypropilen ukuran $20 \times 30 \times 40 \mathrm{~cm}$ yang di tutup dengan kawat kasa, botol minum, tempat makan, sekam alas tidur, sonde lambung, sarung tangan pelindung, kapas, gunting, gluco check Nesco MultiCheck, stik Glukosa Darah Nesco MultiCheck, dextrose 40\%, hewan coba mencit (mice) strain Balb/c.

\section{Prosedur}

\section{Persiapan Hewan Coba (Mice)}

Disiapkan secara acak 30 ekor mencit (mice) betina umur 2-3 bulan dengan berat badan rata-rata 20-25 gram, kemudian dibagi menjadi 4 kelompok yang masingmasing terdiri dari 6 ekor mencit (mice). Kelompok pertama adalah kelompok negatif (tanpa pemberian dekstrosa 40\%, minyak jintan hitam, serta minyak zaitun). Kelompok kedua adalah kelompok kontrol positif (diinjeksi dekstrosa 40\%). Kelompok ketiga diinjeksi dekstrosa $40 \%$, kemudian dilanjutkan diinjeksi minyak jintan hitam dosis 0,7 cc / ekor/ hari. Kelompok keempat diinjeksi dekstroa $40 \%$, dilanjutkan diinjeksi dengan minyak zaitun dosis $0,7 \mathrm{cc} / \mathrm{ekor} / \mathrm{hari}$.

\section{Pengambilan Darah}

Sebelum melakukan pengambilan darah, mencit terlebih dahulu dilakukan uji coba prosedur pengambilan darah mencit (mice). Hal ini dilakukan untuk mencegah kesalahan yang dapat mempengaruhi hasil penelitian selama penelitian berjalan.

Darah diambil melalui ekor mencit (mice). Sebelumnya ekor mencit (mice) dibersihkan terlebih dahulu dari kotoran dan dihangatkan dengan menggunakan minyak menthol atau air hangat untuk memperlancar aliran darah. Selanjutnya ekor mencit digunting $\pm 0,5 \mathrm{~cm}$ dari ujung. Pengambilan darah dilakukan sebelum dan sesudah pemberian dekstrosa $40 \%$ dan selama proses pengobatan atau terapi (pemberian minyak jintan hitam dan minyak zaitun) untuk diperiksa kadar glukosa darahnya (Wiryowidagdo S., 2004). Darah mencit (mice) yang diperoleh langsung diperiksa kadar glukosa darahnya menggunakan alat Nesco MultiCheck tanpa melalui proses penundaan.

\section{Pemberian Minyak Jintan Hitam dan Minyak Zaitun}

Minyak jintan hitam dan minyak zaitun dipipet 0,7 cc/ekor/hari untuk dimasukkan langsung ke dalam lambung mencit (mice) dengan menggunakan sonde lambung. Pemberian minyak jintan hitam dan minyak zaitun pada mencit dilakukan sehari sekali.

\section{Pemeriksaan Kadar Glukosa Darah}

Sampel darah mencit yang diperoleh diperiksa kadar glukosa darahnya menggunakan Nesco MultiCheck Strip. 


\section{HASIL DAN PEMBAHASAN}

\section{Hasil}

Hasil pemeriksaan glukosa darah mencit (mice) yang telah diberi Dekstrosa $40 \%$ dan diterapi dengan minyak jintan hitam dan minyak zaitun dapat dilihat pada Tabel 1 di bawah ini, dengan nilai normal kadar glukosa darah mencit adalah 62,8$176 \mathrm{mg} / \mathrm{dl}$.

Tabel 1. Hasil Pemeriksaan Glukosa Darah Acak Sebelum dilakukan Terapi Minyak Jintan Hitam (JH) dan Minyak Zaitun (MZ)

\begin{tabular}{cc}
\hline No & Kadar Glukosa Darah $(\mathbf{m g} / \mathbf{d l})$ \\
\hline 1 & 220 \\
\hline 2 & 190 \\
\hline 3 & 155 \\
\hline 4 & 143 \\
\hline 5 & 132 \\
\hline 6 & 126 \\
\hline 7 & 173 \\
\hline 8 & 156 \\
\hline 9 & 151 \\
\hline 10 & 143 \\
\hline 11 & 140 \\
\hline 12 & 129 \\
\hline Rata-rata & 154,83
\end{tabular}

Penurunan kadar glukosa dalam pemeriksaan sebelum perlakuan. Hasil darah diketahui melalui selisih antara hasil pemeriksaan sebelum perlakuan dengan penurunan kadar glukosa dalam darah setelah perlakuan dibagi dengan hasil ditunjukkan pada Tabel 2 sebagai berikut :

Tabel 2. Hasil Penurunan Kadar Glukosa Darah Menggunakan Minyak Jintan Hitam (JH) dan Minyak Zaitun (MZ)

\begin{tabular}{ccc}
\hline \multirow{2}{*}{ No } & \multicolumn{2}{c}{ Kadar Glukosa Darah $(\mathbf{m g} / \mathbf{d l})$} \\
\cline { 2 - 3 } & Sesudah Terapi JH & Sesudah Terapi MZ \\
\hline 1 & 162 & 150 \\
\hline 2 & 154 & 143 \\
\hline 3 & 146 & 140 \\
\hline 4 & 126 & 126 \\
\hline 5 & 122 & 122 \\
\hline 6 & 97 & 119 \\
\hline Rata-rata & 134,5 & 133,33 \\
\hline Prosentase & $13,13 \%$ & $13,89 \%$ \\
Penurunan & & \\
\hline
\end{tabular}


Grafik di bawah ini merupakan grafik perbandingan data kadar glukosa darah mencit pada berbagai perlakuan pada selang waktu yang telah ditentukan.

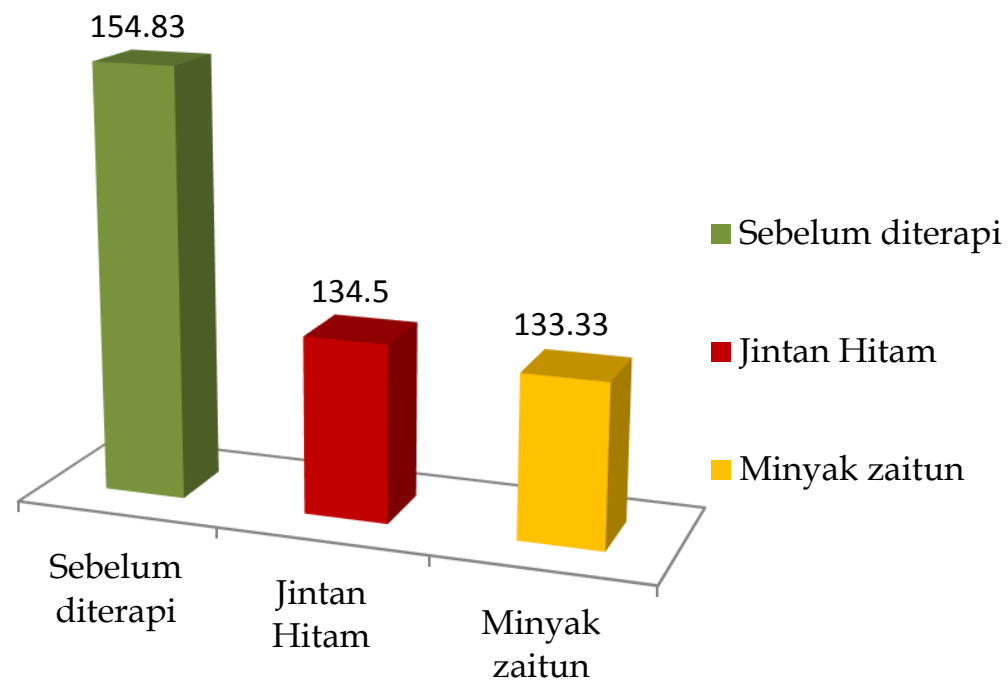

Gambar 1. Grafik perbandingan data kadar glukosa darah mencit pada berbagai perlakuan

Pada kelompok kontrol positif dengan pemberian dekstrosa $40 \%$ terdapat peningkatan kadar glukosa darah dibandingkan kontrol negatif. Pada kelompok kontrol negatif merupakan kelompok yang tidak mengalami perlakuan dan dipakai sebagai nilai normal kadar glukosa darah mencit. Pada kelompok minyak jintan hitam dengan pemberian minyak jintan hitam dosis 0,7 cc/ekor/hari menyebabkan kadar glukosa darah pada mencit mengalami penurunan sebesar 13,13\% yaitu $134 \mathrm{mg} / \mathrm{dl}$. Pada kelompok minyak zaitun dengan pemberian minyak zaitun dosis 0,7 cc/ekor/hari menyebabkan kadar glukosa darah pada mencit mengalami penurunan sebesar 13,89\% yaitu $133 \mathrm{mg} / \mathrm{dl}$.

Hasil uji statistik Independent t-test diperoleh nilai $\mathrm{P}$ (signifikan) sebesar 0,109 . Sedangkan nilai $\alpha$ sebesar 0,05 jadi $(p>\alpha)$ sehingga $H_{o}$ diterima (tidak ada perbedaan / sama). Hal ini berarti tidak ada perbedaan atau sama-sama dapat menurunkan kadar glukosa darah antara yang diterapi dengan menggunakan minyak jintan hitam dan diterapi dengan menggunakan minyak zaitun.

Hasil uji statistik Paired t-test diperoleh nilai $\mathrm{P}$ (Signifikan) sebesar 0,018 . Sedangkan nilai $\alpha$ sebesar 0,05 jadi $(\mathrm{p}<\alpha)$ sehingga $\mathrm{H}_{\mathrm{o}}$ ditolak (ada perbedaan). Hal ini menunjukkan adanya perbedaan kadar glukosa darah antara sebelum dan sesudah diterapi dengan menggunakan minyak jintan hitam.

Hasil uji statistik Paired t-test diperoleh nilai P (Signifikan) sebesar 0,01. Sedangkan nilai $\alpha$ sebesar 0,05 jadi $(\mathrm{p}<\alpha)$ sehingga $\mathrm{H}_{\mathrm{o}}$ ditolak (ada perbedaan). Hal ini menunjukkan adanya perbedaan kadar glukosa darah antara sebelum dan sesudah 
diterapi dengan menggunakan minyak zaitun.

\section{Pembahasan}

Pada kontrol positif dengan pemberian dekstrosa $40 \%$ menyebabkan kadar glukosa darah mencit mengalami peningkatan dibandingkan dengan kontrol negatif. Dekstrosa $40 \%$ adalah monosakarida dijadikan sebagai sumber energi bagi tubuh dan disimpan didalam tubuh sebagai lemak dan diotot dan hati sebagai glikogen. Mekanisme aksi dekstrosa yaitu mengkompensasi kehilangan atau kekurangan karbohidrat dan cairan menjadi sumber nutrisi yang diberikan secara parental dan meningkatkan kadar gula darah pada keadaan hipoglikemia.

Pada penelitian sebelumnya oleh para penelitian dari Universitas Yuzinkwail, Turki, yang dimuat dimajalah Tohoku J Exp Med, September 2003 telah melakukan penelitian terhadap 50 ekor mencit yang dijangkiti penyakit diabetes mellitus dengan diberi zat streptozotocin pada peritoneum (selaput perut). Para peneliti mendapati bahwa pemberian minyak habbatus sauda' pada mencit yang terkena diabetes menyebabkan penurunan kadar gula dalam darah mencit tersebut, serta peningkatan kadar insulin dalam darah. Selain itu, juga menyebabkan pertambahan dan peningkatan aktifitas selsel beta pada pankreas yang bertanggung jawab mensekresikan insulin.

Sedangkan dalam buku karangan De Bruyne tahun 2008 bahwa minyak zaitun merupakan minyak yang mengandung asam lemak tak jenuh tunggal sebagai komponen utamanya. Sebagai komponen terbesar, asam lemak tak jenuh tunggal dalam minyak zaitun memiliki manfaat sebagai terapi nutrisi bagi penderita diabetes melitus. Hal ini dikaitkan dengan peningkatan aktivitas insulin, yaitu meningkatkan sensitivitas insulin pada jaringan yang dituju, peningkatan sekresi insulin, dan memperbaiki sel-sel beta pankreas.

\section{KESIMPULAN}

Dari hasil penelitian, tidak ada perbedaan signifikan pada terapi pemberian minyak jintan hitam dan minyak zaitun terhadap penurunan kadar glukosa darah, karena keduanya samasama dapat menurunkan kadar glukosa darah. Sedangkan minyak zaitun lebih efektif dalam menurunkan kadar glukosa darah jika dibandingkan minyak jintan hitam, karena dari hasil penelitian terdapat perbedaan yang signifikan antara sebelum dan sesudah pemberian minyak zaitun setelah 7 hari pemberian.

\section{UCAPAN TERIMAKASIH}

Penulis mengucapkan terimakasih pada Staf IKHP PUSVETMA Surabaya yang telah banyak membantu selama proses penelitian ini berlangsung.

\section{DAFTAR PUSTAKA}

Al-Majed, A.A., F.A. Al-Omar, M.N. Nagi. 2006. Neuroprotective Effects of Thymoquinone Against Transient Forebrain Ischemia in the Rat hippocampus. European Journal of Pharmacology. 543 : 42-47. http://docs.kso.edo.sa/PDF/Articles3 1/Article310245.pdf. Diakses 12 Maret 2008. 
De Bruyne, L.K., Cataldo, C.B., and Whitney, E.N. 2008. Nutrition and Diet Therapy : Principles and Practice. 7th edition. Belmont : Wadseorth Thomson Learning.

Mangkoewidjojo, S. 2003. Hewan, Eksperimentasi Hewan, Profesi Dokter Hewan, Peranan dan Masalahnya di Bidang Biomedik. Universitas Gadjah Mada. Yogyakarta.

Meral, I., N. Donmez, B. Baydas, F. Belge and M. Kanter. 2004. Effect of Nigella sativa L. on Heart Rate and Some Haematological Values of Alloxan-Induced Diabetic Rabbits. Scand J. Lab. Sci. 31(1) : 49-53.

Miladiyah, I., Purwono dam S. Mustofa. 2003. Efek Ekstrak Eter Daun Ceplukan (Physalis minima Linn) Setelah Pemberian Jangka Panjang Terhadap Kadar Gula Darah Tikus Diabetes. Majalah Obat Tradisional. $8: 10$.

Nickavar, B., F. Mojab, K., Javidnia, M.A.R., Amoli. 2003. Chemical Composition of The Fixed and Volatile Oils of Nigella sativa L. from Iran Zeitchrift fur Nature Forschung. $\quad 58$ : 629-631. http://www.znaturforsch.com.com/ac /v58c 1558c0692.pdf. Diakses 8 Maret 2008.

Nolte, M.S. dan Karam, J.H. 2002. Hormon Pankreas dan Obat Anti Diabetes dalam Basic dan Cliical Pharmacology. 8th ed. Katzung. B.G. (ed) McGraw-Hill Companies Inc. 271-710.

Suryanto. 1993. Pengantar Analisis Kompleks. ITB Press. Bandung.

Tjokroprawiro, A. 2006. Hidup Sehat dan Bahagia Bersama Diabetes Melitus. Gramedia Pustaka Umum. Jakarta. http://jurnal.pdii.lipi.go.id. Diakses 20 September 2011.

Wiryowidagdo, S. 2014. Hasil Penelitian Uji Efikasi Obat Herbal Untuk Meningkatkan Kadar Hemoglobin, Jumlah Trombosit dan Eritrosit dalam Hewan Uji Tikus Putih Jantan. Pusat Studi Bahan Alam. Departemen Farmasi. FMIPA UI. Depok.

Yulianti, S. dan E. Junaedi. 2007. Sembuhkan Penyakit dengan Habbatussauda (Jitan Hitam). Agro Media Pustaka. Jakarta. 